\title{
Identification of Bacterial Fish Pathogens in Brazil by Direct Colony PCR and 16S rRNA Gene Sequencing
}

\author{
F. A. Sebastião, L. R. Furlan, D. T. Hashimoto, F. Pilarski* \\ Aquaculture Center of São Paulo State University-CAUNESP, Universidade Estadual Paulista, Jaboticabal, \\ Brazil \\ Email: ${ }^{*}$ fabianap@caunesp.unesp.br
}

Received 14 May 2015; accepted 11 June 2015; published 16 June 2015

Copyright (C) 2015 by authors and Scientific Research Publishing Inc.

This work is licensed under the Creative Commons Attribution-NonCommercial International License (CC BY-NC).

http://creativecommons.org/licenses/by-nc/4.0/

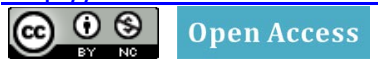

\begin{abstract}
Intensive fish farming systems in Brazil have increased the disease incidence, mainly of bacterial origin, due to higher stocking density, high organic matter levels and poor quality of the aquatic environment that causes high mortality rates during outbreaks. The identification of pathogenic species using a fast and reliable method of diagnosis is essential for successful epidemiological studies and disease control. The present study evaluated the use of direct colony PCR in combination with $16 \mathrm{~S}$ rRNA gene sequencing to diagnose fish bacterial diseases, with the goal of reducing the costs and time necessary for bacterial identification. The method was successful for all 178 isolates tested and produced bands with the same intensity as the standard PCR performed using pure DNA. In conclusion, the genetics methods allowed detecting the most common and important pathogens in Aquaculture, including 12 species of occurrence in Brazilian fish farms. The results of the present study constitute an advance in the available diagnostic methods for bacterial pathogens in fish farms.
\end{abstract}

\section{Keywords}

Direct Colony PCR, 16S rRNA Sequencing, Bacterial Fish Pathogens

\section{Introduction}

Due to its high water availability and favorable climate conditions, Brazil displays high potential for the development of fish farming, which is an activity that has been growing substantially over the last few years. Ac-

\footnotetext{
${ }^{*}$ Corresponding author.
}

How to cite this paper: Sebastião, F.A., Furlan, L.R., Hashimoto, D.T. and Pilarski, F. (2015) Identification of Bacterial Fish Pathogens in Brazil by Direct Colony PCR and 16S rRNA Gene Sequencing. Advances in Microbiology, 5, 409-424. 
cording to the Food and Agriculture Organization of the United Nations [1], Brazil is the second largest aquaculture producer in Latin America and the Caribbean, and freshwater aquaculture (tilapia, carp, and native fish) represented $87 \%$ (545,300 ton) of the total aquaculture production in 2011.

The growing interest in this activity and, consequently, the search for higher profitability, have been leading producers to adopt super-intensive production systems. However, the high density of confined fish, inadequate farming management practices, and water contamination by toxic products cause chronic stress and immunosuppression in farmed animals. These effects lead to the occurrence of diseases and epizootic outbreaks caused by pathogens that would not have high expression in natural environments [2]. Knowledge about the etiological agents, pathogenesis, biochemistry, antigenicity, epizootiology, and inter-relationship of stress and environmental factors of bacterial infections affecting fish is essential to avoid and control diseases. However, these factors have not been well studied, especially because fish farming is a recent activity, with its intensification beginning in the 1990s [3].

Gram-negative bacteria such as Aeromonas, Flavobacterium, Pseudomonas, and Francisella and gram-positive bacteria from the genera Streptococcus and Lactococcus [4]-[11] are some of the pathogens responsible for economic losses in Brazil. They can cause high fish mortality rates up to $72 \mathrm{~h}$ after infection [12].

Although the number of studies focusing on the diagnosis of bacterial etiological agents has increased over the last few years, there are still few available alternatives for the control of fish bacterial infections in Brazil. Therefore, quicker and more effective diagnostic alternatives are necessary, which would help control diseases before they lead to irreversible clinical consequences and high mortality rates. Molecular diagnostic methods use reduced volumes of sample material and exhibit high sensitivity, specificity, and accuracy in pathogen detection [13].

Methods that do not require purified DNA extraction, such as direct colony PCR, are quicker and less expensive and may greatly aid in the early detection of fish pathogens [14]. In addition, because not all microorganism sequences are catalogued in current databases, the use of universal and degenerate primers is a wise strategy. For this reason, methods based on 16S rRNA ribosomal gene amplification and sequencing have been widely explored [13].

The use of universal PCR primers is based on the hypothesis that the primers used are complementary to conserved regions of genes in the environment, resulting in amplification; in turn, heterogeneity is found inside of the fragments flanked by the primers, in hypervariable regions [15] [16]. This method has been revolutionizing microbial ecology, from studies of non-cultivable bacteria to the correct identification of pathogens for accurate diagnoses.

The aim of the present study was to evaluate the direct colony PCR combined with 16S rRNA gene sequencing as a faster and less expensive method to identify fish bacterial pathogens, compared to the classic PCR protocol. Moreover, we have used these methods to demonstrate the efficiency of genetic approaches for the practical evaluation of the diagnosis of aquaculture diseases in Brazilian fish farms.

\section{Materials and Methods}

\subsection{Bacterial Strains and Culture Conditions}

178 bacterial isolates were obtained between 2010 and 2014 from the following hosts $(\mathrm{n}=$ number of assessed fish): tilapia (Oreochromis niloticus $\mathrm{n}=93$ ), tambaqui (Colossoma macropomum $\mathrm{n}=10$ ), carp (Cyprinus carpio $\mathrm{n}=3$ ), cachara (Pseudoplatystoma reticulatum $\mathrm{n}=34$ ), and pacu (Piaractus mesopotamicus $\mathrm{n}=8$ ).

The hosts exhibited clinical signs of bacterial diseases, such as skin ulcerative lesions, hemorrhagic septicemia, meningoencephalitis, fin rot, exophthalmia, and were collected at fish farms in different regions of Brazil:Dourados (Mato Grosso do Sul State, 22¹3'16"S, 5448'20"W, n = 38), Rio de Janeiro (Rio de Janeiro State,

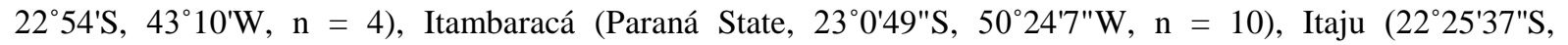

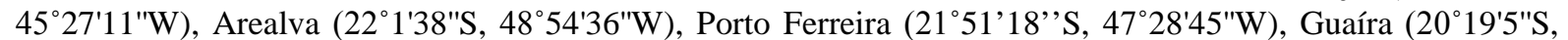

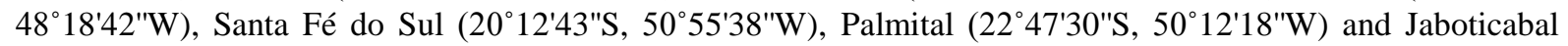
(21 15'19"S, 48¹9'21"W-São Paulo State, $n=123)$.

For the isolation of bacteria, scrapings were performed using sterile swabs on fish kidneys and brain. Gramnegative colonies were plated on TSA (Tryptic Soy Agar-Biolife), and TSB (Tryptic Soy Broth-Biolife) and incubated for $24 \mathrm{~h}$ in bacteriological incubator adjusted to $28^{\circ} \mathrm{C}$. While gram-positive colonies were seeded in Columbia blood agar (Difco) incubated for $24-72 \mathrm{~h}$ at $30^{\circ} \mathrm{C}$ and subcultured in BHI (Brain Heart Infusion 
Broth, Himedia).

The strains of Palmital (SP) were obtained directly from the Laboratory of Aquatic Animal Disease, APTA, Votuporanga, SP.

\subsection{Molecular Identification of Isolates}

Two methods of molecular diagnosis were compared in this study aiming to evaluate the efficiency of direct colony PCR (time and cost effectiveness) in relation to the PCR amplification of purified DNA by extraction, both combined with gene sequencing (Table 1 ).

The standard PCR of purified DNA method followed the steps below.

\subsubsection{DNA Extraction}

One colony of each isolated was transferred to a tube containing appropriate liquid culture medium (TSB for gram-negative and $\mathrm{BHI}$ for gram-positive) and incubated at $28^{\circ} \mathrm{C}$ until the $\mathrm{OD}_{600}$ was between 1 and 1.5. Following incubation, $1.0 \mathrm{~mL}$ of the bacteria culture was centrifuged at $12,000 \times g$ for $1 \mathrm{~min}$, the supernatant was discarded, and the pellet was frozen at $-20^{\circ} \mathrm{C}$ until DNA extraction. The Axyprep ${ }^{\circledR}$ miniprep kit for bacterial genomic DNA was used according to the manufacturer's instructions (Axygen Biosciences, Union City, CA, USA). DNA was quantified by fluorometry using a Qubit 2.0 fluorometer (Life Technologies, NY, USA).

\subsubsection{Standard PCR}

PCR was performed in a $25 \mu \mathrm{L}$ final volume, containing $2.5 \mu \mathrm{L}$ of $10 \mathrm{X}$ buffer (10 mM Tris- $\mathrm{HCl}, 50 \mathrm{mM} \mathrm{KCl})$, $0.2 \mu \mathrm{L}$ of $25 \mathrm{mM}$ dNTP, $1.0 \mu \mathrm{L}$ of $50 \mathrm{mM}$ MgSO4, $0.2 \mu \mathrm{L}$ of Taq High Fidelity (Platinum ${ }^{\circledR} \mathrm{Taq}$ DNA Polymerase, Life Technologies, NY, USA), $2.0 \mu \mathrm{L}$ of each primer (10 pmol), 25 ng of DNA template, and Milli-Q water up to the final volume. The PCR program consisted of $94^{\circ} \mathrm{C}$ for $2 \mathrm{~min}$; 35 cycles of $94^{\circ} \mathrm{C}$ for 30 seconds, $55^{\circ} \mathrm{C}$ for $30 \mathrm{~s}$, and $68^{\circ} \mathrm{C}$ for $1.5 \mathrm{~min}$; and final extension at $68^{\circ} \mathrm{C}$ for $10 \mathrm{~min}$. We used the primers $8 \mathrm{~F} / 907 \mathrm{R}$ (Table 2), specific for the 16S rRNA bacterial gene [15] [17] [18]. The resulting amplicons of approximately 900 bp (base pair) were analyzed by electrophoresis in $1.5 \%$ agarose gel stained with ethidium bromide, according to Sambrook et at. [19].

\subsubsection{Purification of PCR Products and Gene Sequencing}

PCR products were purified using a MinElute Kit (Qiagen, Crawley, West Sussex, UK) according to the manufacturer's instructions. Purified PCR products were quantified using a Qubit 2.0 fluorometer, and gene sequencing was performed using $50 \mathrm{ng} / \mu \mathrm{L}$ per sample. Sequencing was performed according to Sanger [20]. PCR products were amplified using AmpliTaq polymerase and BigDye Terminator (Applied Biosystems) according to the manufacturer's instructions, using the primer 907R. Sequencing was performed using an ABI PRISM 3730 DNA analyzer (Applied Biosystems).

Table 1. Steps of the two methods compared in this study: Standard PCR of purified DNA and direct colony PCR, both combined with the 16S rRNA gene sequencing.

\begin{tabular}{ccc}
\hline Steps & Standard PCR & Direct colony PCR \\
\hline Bacterial isolation & $\mathrm{X}$ & $\mathrm{X}$ \\
Replication in broth & $\mathrm{X}$ & - \\
DNA extraction & $\mathrm{X}$ & $\mathrm{X}$ \\
PCR & $\mathrm{X}$ & $\mathrm{X}$ \\
Electrophoresis & $\mathrm{X}$ & - \\
PCR product purification & $\mathrm{X}$ & $\mathrm{X}$ \\
16S rRNA sequencing & $\mathrm{X}$ & $\mathrm{X}$ \\
Nucleotide analysis & $\mathrm{X}$ & \\
\hline
\end{tabular}


Table 2. Sequence of primers used for amplification of the 16S rRNA gene.

\begin{tabular}{cc}
\hline Primer & Target sequence 5' $\mathbf{3}$ ' \\
\hline $8 \mathrm{~F}$ & AGA GTT TGA TYM TGG CTC AG \\
$907 \mathrm{R}$ & CCG TCA ATT CMT TTR AGT TT \\
\hline
\end{tabular}

\subsection{Direct Colony PCR}

This method allows PCR to be performed on colonies isolated from Petri dishes, without the step of DNA extraction. Colonies (1 - $2 \mathrm{~mm}$ diameter) were inoculated by placing a sterile tooth pick at the bottom of a PCR tube $(0.2 \mathrm{~mL})$ and incubated at $-20^{\circ} \mathrm{C}$ overnight. The following solution was then added in the PCR tube: $2.0 \mu \mathrm{L}$ of $10 \times$ buffer (10 mM Tris-HCl, $50 \mathrm{mM} \mathrm{KCl}), 1.2 \mu \mathrm{L}$ of $50 \mathrm{mM} \mathrm{MgCl}_{2}, 0.2 \mu \mathrm{L}$ of $25 \mathrm{mM}$ dNTP, $0.7 \mu \mathrm{L}$ of each primer 8F/907R (10 pmol/ $\mu \mathrm{L}), 0.2 \mu \mathrm{L}$ of Taq DNA polymerase (2.5 U), and Milli-Q water up to $20 \mu \mathrm{L}$. The PCR program consisted of $95^{\circ} \mathrm{C}$ for $5 \mathrm{~min}$; 30 cycles of $95^{\circ} \mathrm{C}$ for $1 \mathrm{~min}, 54^{\circ} \mathrm{C}$ for $1.5 \mathrm{~min}$, and $72^{\circ} \mathrm{C}$ for $1 \mathrm{~min}$; and final extension at $72^{\circ} \mathrm{C}$ for $5 \mathrm{~min}$. The amplified PCR products, at $50 \mathrm{ng} / \mu \mathrm{L}$ mean concentration, were analyzed by electrophoresis in a $1.5 \%$ agarose gel stained with ethidium bromide [19]. The gels were visualized under UV light, using a ChemiDoc MP imaging system (Bio-Rad). Samples were quantified by fluorometry using a Qubit 2.0 fluorometer and sequenced as described above.

After sequencing, samples of both methods had their nucleotides analyzed.

\subsection{Analysis of Nucleotide Sequences}

The obtained sequences were visualized using the Bio Edit Sequence Alignment Editor software (v. 7.1.11). Phred quality of sequences was determined. The initial and final portions of the sequences were then removed, keeping only the high-quality fragment.

After trim, sequences were exported in FASTA format and compared with the GenBank database (http://www.ncbi.nlm.nih.gov/genbank/) using the Eztaxon algorithm

(http://www.ezbiocloud.net/eztaxon/identify). 100\% coverage and identity $\geq 98 \%$ were considered for specific identification. Sequences were also submitted to Ribosomal Database Project II (http://rdp.cme.msu.edu) for comparison and identification.

The sequences obtained in the present study were deposited at NCBI GenBank under accession numbers KJ560937 to KJ561113. The complete list of species identified, accession numbers, place of origin, fish species, season and year of collection, and size of amplified PCR products were included as Supplementary Material.

The Brazilian isolates tested were S. agalactiae $(\mathrm{n}=23)$, S. iniae $(\mathrm{n}=4)$, Lactococcus lactis $(\mathrm{n}=11)$, L. raffinolactis $(\mathrm{n}=2)$, L. garvieae $(\mathrm{n}=16)$, Enterococcus casseliflavus $(\mathrm{n}=16)$, E. durans $(\mathrm{n}=2)$, E. faecalis $(\mathrm{n}=$ 11), Edwardsiella tarda $(\mathrm{n}=5)$, Aeromonas hydrophila $(\mathrm{n}=16)$, A. jandaei $(\mathrm{n}=2)$, A. veronii $(\mathrm{n}=15)$, Pseudomonas sp. $(\mathrm{n}=15)$.

A phylogenetic diagram was constructed for validation of the sequencing data, using the 138 isolates listed above from the 178 of the present study. In addition, we used as reference 16 sequences originated from different countries (Table 3), obtained from GenBank database.

The 154 FASTA sequences were aligned using the ClustalW Multiple Alignment tool (BioEdit Sequence Alignment Editor software, v. 7.1.11). The data were then entered in Mega software (v. 5.05) to determine the best substitution model. As a result of the preliminary analysis, a maximum-likelihood phylogenetic diagram was constructed, using the Kimura 2-parameter model, with a gamma-shape parameter with 5 categories, the nearest-neighbor-interchange tree inference option. The stability of internal nodes was assessed by bootstrap analysis with 1000 replicates.

\section{Results and Discussion}

\subsection{The Comparison of the Two Methods: Direct Colony PCR and Classic PCR Protocol}

We found no difference in the band size in agarose electrophoresis, nor in the peaks pattern of electropherograms in the two methods evaluated.

Bands resulting from the direct colony PCR exhibited the same intensity as those of the standard PCR of purified DNA, for all 178 isolates tested (Figure 1). 


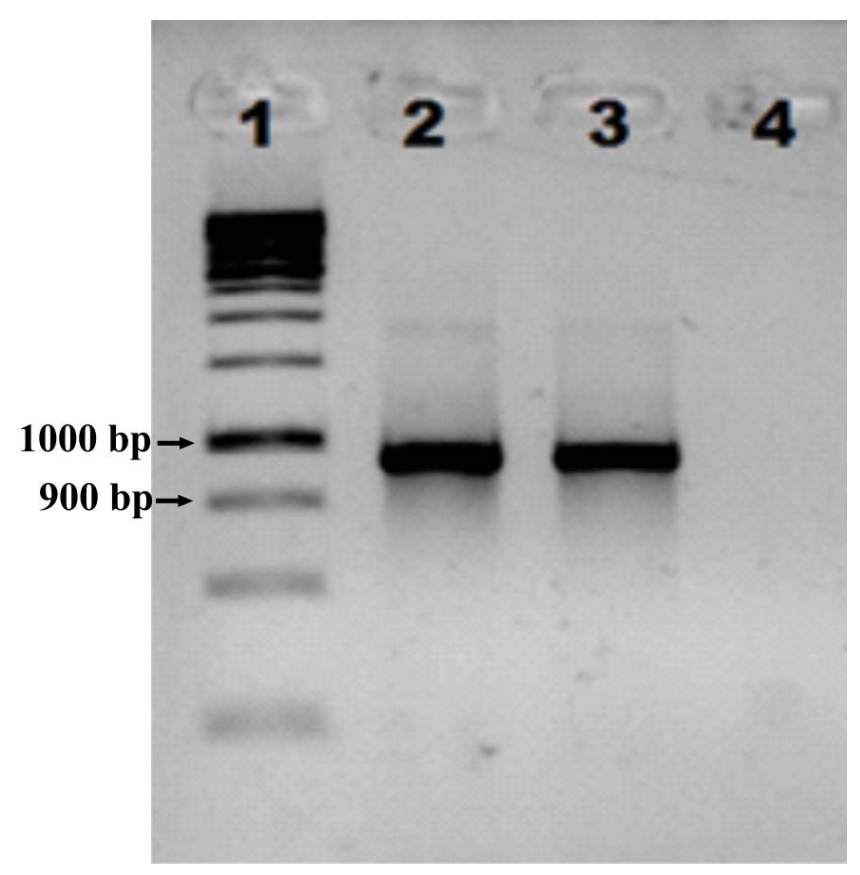

Figure 1. Electropherogram of $1.5 \%$ agarose gel stained with ethidium bromide, showing amplification of 16S rRNA gene (primers 8F/907R). Lane 1, Marker $1 \mathrm{~kb}$. Lane 2, direct colony PCR. Lane 3, standard PCR. Lane 4, negative control.

Table 3. Reference strains used for the maximum-likelihood phylogenetic analysis and their places of origin.

\begin{tabular}{ccc}
\hline Genbank access number & Identification & Origin \\
JX861241 & Aeromonas veronii & India \\
ATCC35624 & Aeromonas veronii & Japan \\
NR_074841 & Aeromonas hydrophila & USA \\
JN644061 & Aeromonas jandaei & China \\
ATCC49568 & Aeromonas jandaei & India \\
NBRC_105688 & Edwardsiella tarda & Japan \\
EU239205 & Pseudomonas fulva & Korea \\
KC210866 & Enterococcus casseliflavus & China \\
AB530699 & Enterococcus faecalis & Thailand \\
NR_036922 & Enterococcus durans & Germany \\
KC176716 & Streptococcus agalactiae & China \\
NR_027517 & Streptococcus dysgalactiae & Japan \\
NR_025148 & Streptococcus iniae & Israel \\
NR_044359 & Lactococcus raffinolactis & Sactococcus lactis \\
KC429785 & Lactococcus garvieae & China \\
ATCC49156 & USA \\
\hline
\end{tabular}


Electropherograms resulting from the sequencing of both methods exhibited Phred quality scores $\geq 20$. All the isolates had the same results of bacterial identification for both techniques (direct colony PCR and standard PCR of purified DNA). Thus, direct colony PCR was a less expensive and faster diagnostic method, as shown on Table 4. There were 51\% savings in cost analysis per sample for direct colony PCR compared to Standard PCR of purified DNA. Moreover, direct colony PCR reduces 2 days in time to issue the final report. After the installation of a bacterial outbreak, fish shoals can be decimated by up to 72 hours. Therefore, rapid diagnosis in aquaculture is a critical point in the production chain, which can be assessed by the genetic tools of the present study.

A faster diagnosis is important, since the one based on classical microbiology techniques (isolation, platting and biochemical tests) can exceed the time for treatment in seven to 15 days and, in many cases, ending up inconclusive. The molecular diagnosis, on the other hand, can provide a faster, low cost, conclusive diagnosis, which is essential to determine the best treatment in fish farming (Table 5).

Besides, in an attempt to control disease outbreaks, in classical scenery in Brazil, producers use multiple antibiotics indiscriminately, selecting resistant strains, contaminating fish, water and raising the risks to consumer health, endorsing the need for rapid and effective diagnosis [21].

A maximum-likelihood phylogenetic tree was built to validate the sequencing data (Figure 2). The bacterial isolates of the same species or phylogenetic related were correctly grouped into a common branch, as expected. The principle of maximum likelihood for phylogenetic inference evaluates the probability of a given model of evolutionary changes explaining the origin of the data observed. In this method, the initial tree is constructed using the neighbor-joining method, and the length of each branch is adjusted to maximize the likelihood that the information will produce the topology of the tree for the desired evolutionary model [22].

These results confirm and validate the direct colony PCR method to be applied as a reliable tool for the identification of bacterial fish pathogens in aquaculture. Although this method has already been used in previous studies for different purposes [14] [23], the present study represents the first practical application for the diagnosis of aquaculture diseases, a field lacking in terms of technological advancement.

Table 4. Cost analysis per sample for bacterial identification, performed in university laboratory already equipped.

\begin{tabular}{|c|c|c|c|c|}
\hline \multirow[b]{2}{*}{ Steps } & \multicolumn{2}{|c|}{ Standard PCR } & \multicolumn{2}{|c|}{ Direct colony PCR } \\
\hline & U\$ & Time & U\$ & Time \\
\hline Bacterial isolation on plate & 0.31 & $24-72 \mathrm{~h}$ & 0.31 & $24-72 \mathrm{~h}$ \\
\hline Replication in broth & 0.41 & $24-48 \mathrm{~h}$ & - & - \\
\hline DNA extraction & 5.6 & $1-3 h$ & - & - \\
\hline PCR & 2.52 & $3 \mathrm{~h}$ & 2.52 & $3 \mathrm{~h}$ \\
\hline Electrophoresis & 0.27 & $1.5 \mathrm{~h}$ & 0.27 & $1.5 \mathrm{~h}$ \\
\hline PCR product purification & 2.54 & $1 \mathrm{~h}$ & - & - \\
\hline 16S rRNA sequencing & 5.0 & $24 \mathrm{~h}$ & 5.0 & $24 \mathrm{~h}$ \\
\hline Nucleotide analysis & - & $1 \mathrm{~h}$ & - & $1 \mathrm{~h}$ \\
\hline Overall & 16.65 & 4 - 7 days & 8.1 & 3 - 5 days \\
\hline
\end{tabular}

*Isolation times vary depending on the species being cultured.

Table 5. Advantages and disadvantages of each method for aquaculture diagnosis.

\begin{tabular}{lccc}
\hline & Classical microbiology & Standard PCR & Colony PCR \\
\hline Advantages & Less technicization & $\begin{array}{c}\text { Conclusive diagnosis, faster than } \\
\text { the classical Microbiology }\end{array}$ & $\begin{array}{c}\text { Conclusive diagnosis; 51\% more economical; } \\
24-48 \mathrm{~h} \text { faster than standard PCR. }\end{array}$ \\
Disadvantages & $\begin{array}{c}\text { Inconclusive and time } \\
\text { consuming diagnosis }\end{array}$ & It depends on bacterial culture & $1 \%$ to $3 \%$ can fail; \\
& & & Still depends bacterial culture \\
\hline
\end{tabular}




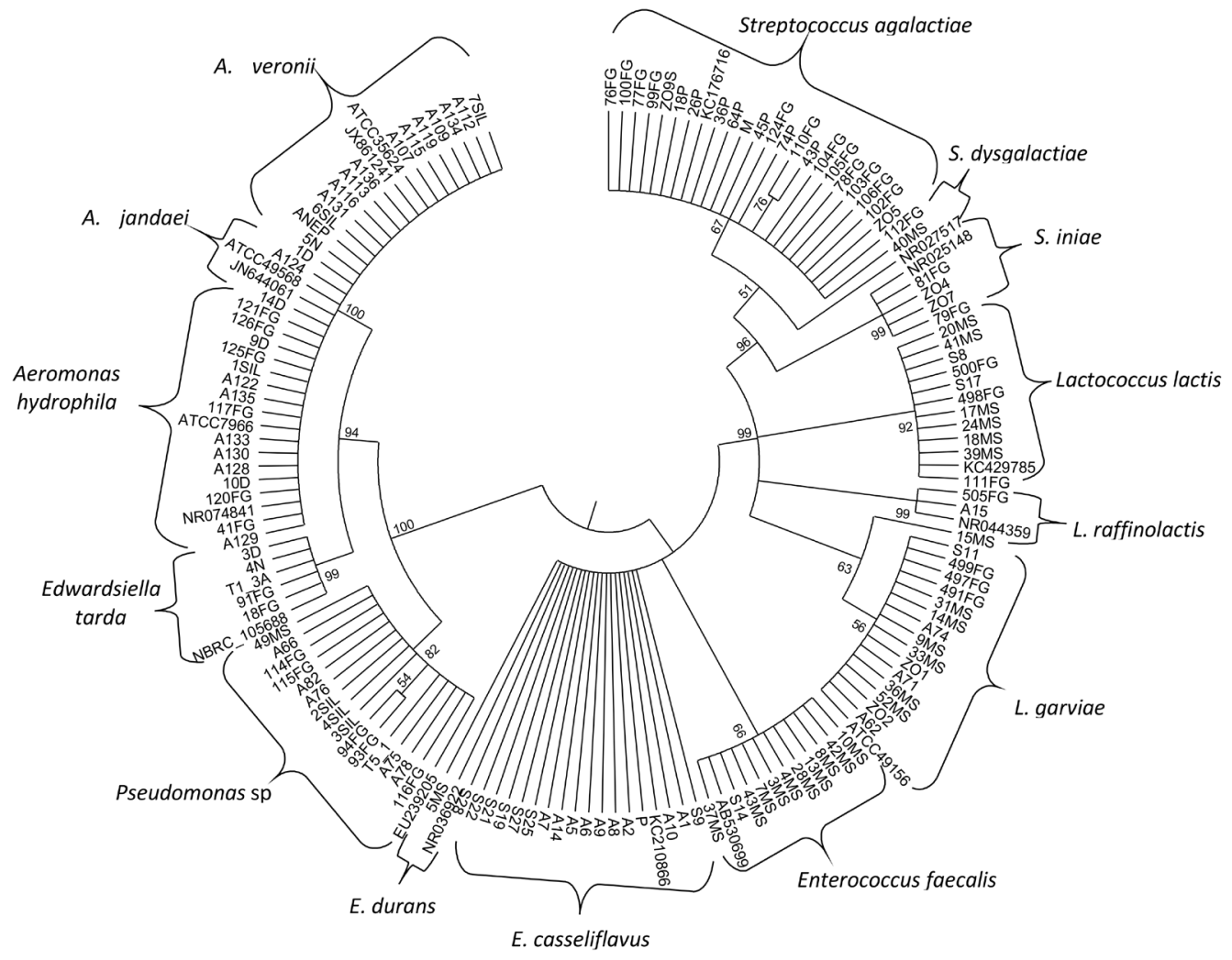

Figure 2. Relationship among different bacteria species using 16S rRNA gene sequences, inferred by maximum-likelihood method. The phylogenetic diagram shows the correct clustering of related fish bacteria isolated in the present study.

\subsection{The Analysis of the Common Bacterial Fish Pathogens}

Direct colony PCR, combined with gene sequencing, was able to detect the most common and important pathogens in aquaculture, such as Aeromonas hydrophila, Aeromonas veronii, Aeromonas jandaei, Streptococcus agalactiae, Streptococcus iniae, Streptococcus dysgalactiae, Edwardsiella tarda, Pseudomonas sp., Lactococcus garvieae, Citrobacter freundii, Plesiomonas shigelloides, and Enterococcus sp.

As shown in Figure 3, genera related to pathogenic bacteria and with higher frequency among 178 bacterial isolates of this study were Aeromonas (31\%), Lactococcus (23\%), Enterococcus (22\%), Streptococcus (20\%), Pseudomonas (11\%), Citrobacter (6\%), Edwardsiella (5\%), Acinetobacter (3\%), Enterobacter (2\%), Plesiomonas (1\%) and Weissela (1\%).

Of the 43 Aeromonas isolates, 53\% were identified as A. hydrophila by $16 \mathrm{~S}$ rRNA gene sequencing. This result is in accordance with previous reports that found this species to be predominant [24]. In turn, A. veronii corresponded to $40 \%$ of the isolates. The seasonality was also observed in the present study: at higher temperatures (Spring/Summer) there were higher isolation rates of these pathogens [25], which causes hemorrhagic septicemia, characterized by small superficial lesions, focal hemorrhages, ulcers, abscesses, and abdominal distension. Internally, there can be ascitic fluid accumulation, anemia, and lesions in the liver and kidneys [26].

For the genus Lactococcus, the emerging species L. garvieae corresponded to $52 \%$ of the total 29 isolates of this genus, followed by L. lactis with $41 \%$ incidence in fish originating from the states included in the present study, with higher incidence in $P$. reticulatum. The species $L$. garvieae has been isolated from several fish species worldwide, namely in Japan [27], South Africa [28], Europe [29], and Brazil. Its first outbreak was reported in 2009 [7]. Fish with lactococcal infection exhibit lethargy, anorexia, skin darkening and swim closer to the water surface [30], resulting in considerable economic losses, especially during the summer months when the water temperature increases [4]. Few studies report L. lactis as an opportunistic pathogen. However, L. lactis subsp. lactis has been responsible for a $100 \%$ loss of hybrid sturgeons (Huso huso $\times$ Acipenser ruthenus) in a fish farm in Taiwan, China [31]. 


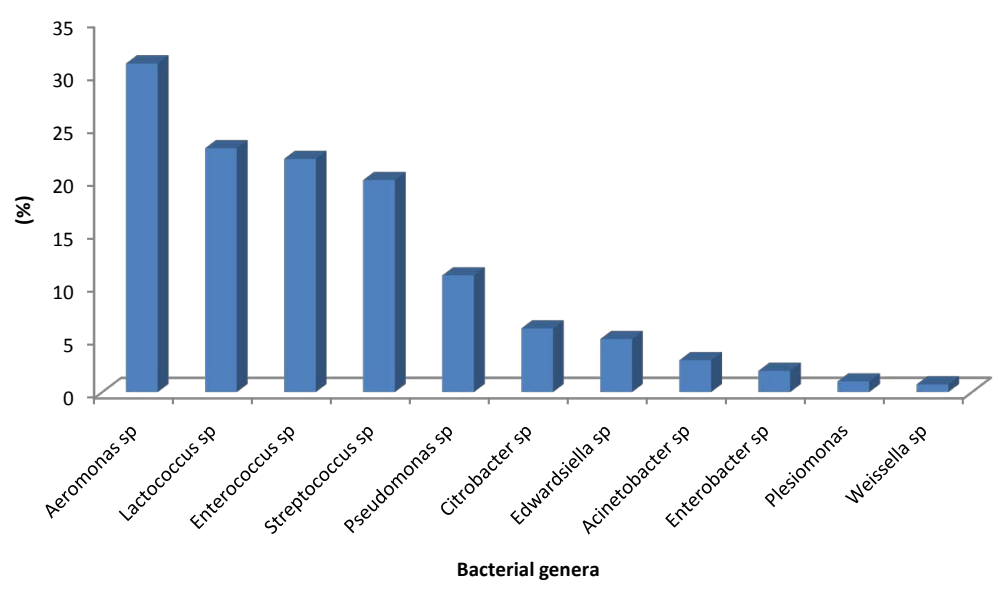

Figure 3. Percentage of bacterial genera identified by 16S rRNA gene of the 178 isolates of this study distributed in the states of Mato Grosso do Sul, São Paulo, Paraná and Rio de Janeiro.

In the present study, 31 Enterococcus strains were isolated from skin and kidney samples. Of these, 55\% were E. casseliflavus, 36\% E. faecalis, 6\% E.durans, and 3\% E. sulfureus. The predominance of E. casseliflavus has also been observed among isolates from water and sediment, accounting for $66.7 \%$ of a total of 410 Enterococcus sp. isolates in Thailand [32].

Of the 27 Streptococcus strains originating from the states of Mato Grosso do Sul, Paraná, and São Paulo, 89\% corresponded to S. agalactiae; this was previously observed by Netto et al. [33] and Figueiredo et al. [10]. Although infection by S. agalactiae is the main cause of losses in tilapia farming worldwide, this pathogen has also been isolated from "cachara” originating from Mato Grosso do Sul. S. agalactiae has been identified in several other fish species, such as Sparus auratus, Liza klunzingeri [34], and Pampusargenteus [35]. Infected fish have meningoencephalitis, exophthalmia, erratic swimming, mainly.

The species $P$. putida (27\%) and $P$. fulva (20\%) were the predominant Pseudomonas species observed $(\mathrm{n}=$ 15). Eissa et al. [36] observed an incidence of 30.83\% of Pseudomonas species in Nile tilapia in Egypt. Hussain [37] and Zorrilla et al. [38] reported 13.5\%, and 9.7\% incidence, respectively, of Pseudomonas species in marine fish, values that are similar to the $11 \%$ incidence found in the present study. $P$. fluorescens, $P$. angulliseptica, $P$. aeruginosa and $P$. putida were identified in various species of fish as causative agents of Pseudomonas septicemia. The disease is characterized by petechial hemorrhage, darkness of the skin, detached scales, abdominal ascitis and exophthalmia [39].

As the number of isolates from each region was dissimilar and low, it would not be advisable to determine a frequency profile of pathogens by location, neither the prevalence of bacterial genera by fish species, but we emphasize the importance of drawing a regional profile in aquaculture health monitoring programs and preventive management, therefore, in case of disease outbreak, treatment measures are different in each region, since factors such as light, water quality and soil contamination, quantity of parasites, management, etc are also peculiar to each locality.

\section{Conclusion}

Direct colony PCR combined with 16S rRNA gene sequencing constitutes an efficient alternative for diagnosing bacterial fish diseases, with decreased cost and time compared with the classical methods used in Brazil, such as isolation, biochemical tests, and conventional PCR.

\section{Acknowledgements}

The author wishes to thank the State of São Paulo Research Foundation (FAPESP-Process 2011/07951-5) for the financial support; the Aquaculture Center (CAUNESP/UNESP, Jaboticabal) and the Laboratory of Microbial and Plant Biochemistry, Technology Department (Laboratório de Bioquímica de Microrganismos e Plantas, FCAV/UNESP Jaboticabal), UNESP, for technical support; and Dr. Fabiana Garcia for donating the bacterial strains. 


\section{References}

[1] FAO Fishery and Aquaculture Country Profiles. Brazil (2010) Country Profile Fact Sheets. FAO Fisheries and Aquaculture Department [online]. Rome. Updated 1 June 2010.

[2] Dash, S.S., Dasi, B.K., Pattnaik, P., Samal, S.K., Sahu, S. and Ghosh, S. (2009) Biochemical and Serological Characterization of Flavobacterium columnare from Freshwater Fishes of Eastern India. Journal of World Aquaculture Society, 40, 236-247. http://dx.doi.org/10.1111/j.1749-7345.2009.00246.x

[3] Shama, S., Brandão, D.A., Vargas, A.C., Costa, M.M. and Pedrozo, A.F. (2000) Bactérias com potencial patogênico nos rins e lesões externas de jundiás (Rhamdia quelen) cultivados em sistema semi-intensivo. Ciência Rural, 30, 293298. http://dx.doi.org/10.1590/S0103-84782000000200016

[4] Vendrell, D., Balcazar, J.L., Ruiz-Zarzuela, I., Blas, I.D., Girones, O. and Muzquiz, J.L. (2006) Lactococcus garvieae in Fish: A Review. Comparative Immunology, Microbiology and Infectious Diseases, 29, 177-198. http://dx.doi.org/10.1016/j.cimid.2006.06.003

[5] Olivares-Fuster, O., Klesius, P.H., Evans, J. and Arias, C.R. (2008) Molecular Typing of Streptococcus agalactiae Isolates from Fish. Journal of Fish Diseases, 31, 277-283. http://dx.doi.org/10.1111/j.1365-2761.2007.00900.x

[6] Staroscik, A.M., Hunnicutt, D.W., Archibald, K.E. and Nelson, D.R. (2008) Development of Methods for the Genetic Manipulation of Flavobacterium columnare. BMC Microbiology, 8, 115. http://www.biomedcentral.com/1471-2180/8/115

[7] Evans, J.J., Klesius, P.H. and Shoemaker, C.A. (2009) First Isolation and Characterization of Lactococcus garvieae from Brazilian Nile Tilapia, Oreochromis niloticus (L.), and Pintado, Pseudoplathystoma corruscans (Spix \& Agassiz). Journal of Fish Diseases, 32, 943-951. http://dx.doi.org/10.1111/j.1365-2761.2009.01075.x

[8] Birkbeck, T.H., Feist, S.W. and Verner-Jeffreys, D.W. (2011) Francisella Infections in Fish and Shellfish. Journal of Fish Diseases, 34, 173-187. http://dx.doi.org/10.1111/j.1365-2761.2010.01226.x

[9] Burr, S.E., Goldschmidt-Clermont, E., Kuhnert, P. and Frey, J. (2012) Heterogeneity of Aeromonas Populations in Wild and Farmed Perch, Perca fluviatilis L. Journal of Fish Diseases, 35, 607-613.

http://dx.doi.org/10.1111/j.1365-2761.2012.01388.x

[10] Figueiredo, H.C.P., Nobrega-Netto, L., Leal, C.A.G., Pereira, U.P. and Mian, G.F. (2012) Streptococcus iniae Outbreaks in Brazilian Nile Tilapia (Oreochromis niloticus L.) Farms. Brazilian Journal of Microbiology, 43, 576-580. http://dx.doi.org/10.1590/S1517-83822012000200019

[11] Beaz-Hidalgo, R. and Figueras, M.J. (2012) Molecular Detection and Characterization of Furunculosis and Other Aeromonas Fish Infections. In: Carvalho, E., Ed., Health and Environment in Aquaculture, InTech Open Access Publisher, 97-132. http://dx.doi.org/10.5772/29901

[12] Silva, B.C., Mouriño, J.L.P., Vieira, F.N., Jatobá, A., Seiffert, W.Q. and Martins, M.L. (2012) Haemorrhagic Septicaemia in the Hybrid Surubim (Pseudoplatystoma corruscans $\times$ Pseudoplatystoma fasciatum) Caused by Aeromonas hydrophila. Aquaculture Research, 43, 908-916. http://dx.doi.org/10.1111/j.1365-2109.2011.02905.x

[13] Janda, J.M. and Abbott, S.L. (2007) 16S rRNA Gene Sequencing for Bacterial Identification in the Diagnostic Laboratory: Pluses, Perils, and Pitfalls. Journal of Clinical Microbiology, 45, 2761-2764. http://dx.doi.org/10.1128/JCM.01228-07

[14] Coton, E. and Coton, M. (2005) Multiplex PCR for Colony Direct Detection of Gram-Positive Histamine- and Tyramine-Producing Bacteria. Journal of Microbiological Methods, 63, 296-304. http://dx.doi.org/10.1016/j.mimet.2005.04.001

[15] Ben-Dov, E., Shapiro, O.H., Siboni, N. and Kushmaro, A. (2006) Advantage of Using Inosine at the 3' Termini of 16S rRNA Gene Universal Primers for the Study of Microbial Diversity. Applied and Environmental Microbiology, 72, 6902-6906. http://dx.doi.org/10.1128/AEM.00849-06

[16] Claesson, M.J., Wang, Q., O’Sullivan, O., Greene-Diniz, R., Cole, J.R., Ross, R.P. and O’Toole, P.W. (2010) Comparison of Two Next-Generation Sequencing Technologies for Resolving Highly Complex Microbiota Composition Using Tandem Variable 16S rRNA Gene Regions. Nucleic Acids Research, 38, e200. http://dx.doi.org/10.1093/nar/gkq873

[17] Lane, D.J., Pace, B., Olsen, G.J., Stahlt, D.A., Sogint, M.L. and Pace, N.R. (1985) Rapid Determination of 16S Ribosomal RNA Sequences for Phylogenetic Analyses. Proceedings of the National Academy of Sciences of the United States of America, 82, 6955-6959. http://dx.doi.org/10.1073/pnas.82.20.6955

[18] Felske, A., Rheims, H., Wolterink, A., Stackebrandt, E. and Akkermans, A.D. (1997) Ribosome Analysis Reveals Prominent Activity of an Uncultured Member of the Class Actinobacteria in Grassland Soils. Microbiology, 143, 29832989. http://dx.doi.org/10.1099/00221287-143-9-2983

[19] Sambrook, J. and Russel, D.W. (2001) Molecular Cloning. 3rd Edition, Cold Spring Harbor Laboratory Press, New 
York.

[20] Sanger, F., Nicklen, S. and Coulson, A.R. (1977) DNA Sequencing with Chain-Terminating Inhibitors. Proceedings of the National Academy of Sciences of United States of America, 74, 5463-5467. http://dx.doi.org/10.1073/pnas.74.12.5463

[21] Meireles, M.A.O.M. (2008) Uso de antimicrobianos e resistência bacteriana: Aspectos socioeconômicos e comportamentais e seu impacto clínico e ecológico. Monograph (Microbiology Expert). Universidade Federal de Minas Gerais, Belo Horizonte.

[22] Tamura, K., Peterson, D., Peterson, N., Stecher, G., Nei, M. and Kumar, S. (2011) MEGA5: Molecular Evolutionary Genetics Analysis Using Maximum Likelihood, Evolutionary Distance, and Maximum Parsimony Methods. Molecular Biology and Evolution, 10, 2731-2739. http://dx.doi.org/10.1093/molbev/msr121

[23] Kong, P., Richardson, P.A. and Hong, C.X. (2005) Direct Colony PCR-SSCP for Detection of Multiple Pythiaceous Oomycetes in Environmental Samples. Journal of Microbiological Methods, 61, 25-32. http://dx.doi.org/10.1016/j.mimet.2004.10.019

[24] Belem-Costa, A. and Cyrino, J.E.P. (2006) Antibiotic Resistence of Aeromonas hydrophila Isolated from Piaractus mesopotamicus (Holmberg, 1887) and Oreochromis niloticus (Linnaeus, 1758). Scientia Agricola, 63, 281-284. http://dx.doi.org/10.1590/S0103-90162006000300011

[25] Pereira, C.S., Amorim, S.D., Santos, A.F.M., Reis, C.M.F., Theophilo, G.N.D. and Rodrigues, D.P. (2008) Characterization of Aeromonas spp. Isolates from Newborns Hospitalized. Revista da Sociedade Brasileira de Medicina Tropical, 41, 179-182. http://dx.doi.org/10.1590/S0037-86822008000200009

[26] Garcia, F., Pilarski, F., Onaka, E.M., Moraes, F.R. and Martins, M.L. (2007) Hematology of Piaractus mesopotamicus Fed Diets Supplemented with Vitamins C and E, Challenged by Aeromonas hydrophila. Aquaculture, 271, 39-46. http://dx.doi.org/10.1016/j.aquaculture.2007.06.021

[27] Nishiki, I., Furukawa, M., Matui, S., Itami, T., Nakai, T. and Yoshida, T. (2011) Epidemiological Study on Lactococcus garvieae Isolates from Fish in Japan. Fisheries Science, 77, 367-373. http://dx.doi.org/10.1007/s12562-011-0332-0

[28] Bekker, A., Hugo, C., Albertyn, J., Boucher, C.E. and Bragg, R.R. (2011) Pathogenic Gram-Positive Cocci in South African Rainbow Trout, Oncorhynchus mykiss (Walbaum). Journal of Fish Diseases, 34, 483-487. http://dx.doi.org/10.1111/j.1365-2761.2011.01259.x

[29] Eyngor, M., Zlotkin, A., Ghittino, C., Prearo, M., Douet, D.G., Chilmonczyk, S. and Eldar, A. (2004) Clonality and Diversity of the Fish Pathogen Lactococcus garvieae in Mediterranean Countries. Applied and Environmental Microbiology, 70, 5132-5137. http://dx.doi.org/10.1128/AEM.70.9.5132-5137.2004

[30] Avci, H., Aydoğan, A., Tanrikul, T.T. and Birincioğlu, S.S. (2010) Pathological and Microbiological Investigations in Rainbow Trout (Oncorhynchus mykiss Walbaum, 1792) Naturally Infected with Lactococcus garvieae. Kafkas Üniversitesi Veteriner Fakültesi Dergisi, 16, S313-S318.

[31] Chen, M.H., Hung, S.W., Shyu, C.L., Lin, C.C., Liu, P.C., Chang, C.H., Shia, W.Y., Cheng, C.F., Lin, S.L., Tu, C.Y., Lin, Y.H. and Wang, W.S. (2012) Lactococcus lactis Subsp. Lactis Infection in Bester Sturgeon, a Cultured Hybrid of Huso huso $\times$ Acipenser ruthenus, in Taiwan. Research in Veterinary Science, 93, 581-588. http://dx.doi.org/10.1016/j.rvsc.2011.10.007

[32] Petersen, A. and Dalsgaard, A. (2003) Species Composition and Antimicrobial Resistance Genes of Enterococcus spp., Isolated from Integrated and Traditional Fish Farms in Thailand. Environmental Microbiology, 5, 395-402. http://dx.doi.org/10.1046/j.1462-2920.2003.00430.x

[33] Netto, L.N., Leal, C.A.G. and Figueiredo, H.C.P. (2011) Streptococcus dysgalactiae as an Agent of Septicaemia in Nile Tilapia, Oreochromis niloticus (L.). Journal of Fish Diseases, 34, 251-254. http://dx.doi.org/10.1111/j.1365-2761.2010.01220.x

[34] Evans, J.J., Wiedenmayer, A.A. and Klesius, P.H. (2002) A Transport System for Maintenance of Viability of Acinetobacter calcoaceticus, Streptococcus iniae, and Streptococcus agalactiae over Varying Time Periods. Bulletin of the European Association of Fish Pathologists, 22, 238-246.

[35] Duremdez, R., Al-Marzouk, A. and Qasem, J.A. (2004) Isolation of Streptococcus agalactiae from Cultured Silver Pomfret, Pampus argenteus (Euphrasen), in Kuwait. Journal of Fish Diseases, 27, 307-310. http://dx.doi.org/10.1111/j.1365-2761.2004.00538.x

[36] Eissa, N.M.E., Abou, E.E.N., Shaheen, A.A. and Abbass, A. (2010) Characterization of Pseudomonas Species Isolated from Tilapia “Oreochromis niloticus" in Qaroun and Wadi-El-Rayan Lakes, Egypt. Global Veterinaria, 5, 116-121.

[37] Hussain, R.A. (2002) Studies on Some Bacterial Infections Affecting Certain Marine Fishes in the Arabian Gulf of Kingodom of Saudi Arabia. Ph.D. Dissertation., Faculty of Veterinary Medicine and Animal Resources, King Faisal University, Al-Ahsa.

[38] Zorrilla, I., Chabrillón, M., Arijo, S., Díaz-Rosales, P., Martínez-Manzanares, E., Balebona, M.C. and Moriñigo, M.A. 
(2003) Bacteria Recovered from Diseased Cultured Gilthead Sea Bream (Sparus aurata L.) in Southwestern Spain. Aquaculture, 218, 11-20. http://dx.doi.org/10.1016/S0044-8486(02)00309-5

[39] Austin, B. and Austin, D.A. (2007) Bacterial Fish Pathogens. Diseases of Farmed and Wild Fish. Springer-Praxis Publishing, Ltd., Chichester.

\section{Supplementary Data}

\begin{tabular}{|c|c|c|c|c|c|c|c|}
\hline $\begin{array}{c}\text { GenBank } \\
\text { accession numbers }\end{array}$ & Sample & Fish & Organ & Molecular identification & Location & Time & Molecular size (bp) \\
\hline KJ560937 & $4 n$ & Tilapia & Skin & Edwardsiella tarda & Nepean, Jaboticabal sp & Spring 2013 & 868 \\
\hline KJ560938 & T1.3a & Tilapia & Gills & Edwardsiella tarda & Porto Ferreira SP & Spring 2013 & 825 \\
\hline KJ560939 & 2dp & Tilapia & Kidney & Edwardsiella tarda & Porto Ferreira SP & Spring 2013 & 855 \\
\hline KJ560940 & $18 \mathrm{FG}$ & Tilapia & Skin & Edwardsiella tarda & Rio Paranapanema (SP/PR) & Winter 2012 & 858 \\
\hline KJ560941 & $91 \mathrm{FG}$ & Tilapia & Skin & Edwardsiella tarda & Rio Paranapanema (SP/PR) & Winter 2012 & 860 \\
\hline KJ560942 & $8 g$ & Pacu & Kidney & Edwardsiella tarda & Caunesp, Jaboticabal, SP & Spring 2013 & 847 \\
\hline KJ560943 & 3dp & Tilapia & Kidney & Edwardsiella tarda & Porto Ferreira SP & Spring 2013 & 873 \\
\hline KJ560944 & $45 \mathrm{MS}$ & Cachara & Skin & Enterobacter asburiae & MS & Winter 2012 & 851 \\
\hline KJ560945 & 47MS & Cachara & Kidney & Kosakonia cowanii & MS & Winter 2012 & 857 \\
\hline KJ560946 & 48MS & Cachara & Kidney & Enterobacter ludwigii & MS & Winter 2012 & 800 \\
\hline KJ560947 & A77 & Tilapia & Kidney & Enterobacter kobei & Arealva SP & Spring 2011 & 830 \\
\hline KJ560948 & A79 & Tilapia & Kidney & Enterobacter kobei & Arealva SP & Spring 2011 & 853 \\
\hline KJ560949 & A70 & Tilapia & Skin & Enterobacter ludwigii & Arealva SP & Spring 2011 & 855 \\
\hline KJ560950 & A1 & Tambaqu & Skin & Enterococcus casseliflavus & s Caunesp, Jaboticabal SP & Spring 2011 & 859 \\
\hline KJ560951 & A8 & Tambaqui & i Skin & Enterococcus casseliflavus & s Caunesp, Jaboticabal SP & Spring 2011 & 857 \\
\hline KJ560952 & A5 & Tambaqui & i Skin & Enterococcus casseliflavus & s Caunesp, Jaboticabal SP & Spring 2011 & 869 \\
\hline KJ560953 & A9 & Tambaqui & i Skin & Enterococcus casseliflavus & s Caunesp, Jaboticabal SP & Spring 2011 & 860 \\
\hline KJ560954 & A2 & Tambaqui & Skin & Enterococcus casseliflavus & s Caunesp, Jaboticabal SP & Spring 2011 & 866 \\
\hline KJ560955 & A6 & Tambaqui & Skin & Enterococcus casseliflavus & s Caunesp, Jaboticabal SP & Spring 2011 & 841 \\
\hline KJ560956 & A10 & Tambaqui & Skin & Enterococcus casseliflavus & s Caunesp, Jaboticabal SP & Spring 2011 & 862 \\
\hline KJ560957 & A7 & Tambaqui & i Skin & Enterococcus casseliflavus & s Caunesp, Jaboticabal SP & Spring 2011 & 862 \\
\hline KJ560958 & A14 & Tilapia & Skin & Enterococcus casseliflavus & s Caunesp, Jaboticabal SP & Spring 2011 & 856 \\
\hline KJ560959 & $\mathrm{P}$ & Tilapia & Brain & Enterococcus casseliflavus & Itambaracá PR & Summer 2010 & 853 \\
\hline KJ560960 & S27 & Tilapia & Kidney & Enterococcus casseliflavus & Caunesp, Jaboticabal & Winter 2011 & 879 \\
\hline KJ560961 & S22 & Tilapia & Skin & Enterococcus casseliflavus & s Caunesp, Jaboticabal SP & Winter 2011 & 871 \\
\hline KJ560962 & S28 & Tilapia & Brânquia & a Enterococcus casseliflavus & Caunesp, Jaboticabal & Winter 2011 & 876 \\
\hline
\end{tabular}




\begin{tabular}{|c|c|c|c|c|c|c|c|}
\hline \multicolumn{8}{|l|}{ Continued } \\
\hline KJ560963 & S21 & Tilapia & Skin & Enterococcus casseliflavus & Caunesp, Jaboticabal SP & Winter 2011 & 871 \\
\hline KJ560964 & S19 & Tilapia & Skin & Enterococcus casseliflavus & Caunesp, Jaboticabal SP & Winter 2011 & 867 \\
\hline KJ560965 & S25 & Tilapia & Skin & Enterococcus casseliflavus & Caunesp, Jaboticabal SP & Winter 2011 & 872 \\
\hline KJ560966 & $5 \mathrm{MS}$ & Cachara & Kidney & Enterococcus durans & MS & Spring 2012 & 840 \\
\hline KJ560967 & S9 & Tilapia & Skin & Enterococcus durans & Arealva SP & Spring 2011 & 874 \\
\hline KJ560968 & 3 MS & Cachara & Kidney & Enterococcus faecalis & MS & Spring 2012 & 854 \\
\hline KJ560969 & $4 \mathrm{MS}$ & Cachara & Kidney & Enterococcus faecalis & MS & Spring 2012 & 840 \\
\hline KJ560970 & $7 \mathrm{MS}$ & Cachara & Kidney & Enterococcus faecalis & MS & Spring 2012 & 846 \\
\hline KJ560971 & $8 \mathrm{MS}$ & Cachara & Kidney & Enterococcus faecalis & MS & Spring 2012 & 837 \\
\hline KJ560972 & 10MS & Cachara & Kidney & Enterococcus faecalis & MS & Spring 2012 & 852 \\
\hline KJ560973 & $13 \mathrm{~ms}$ & Cachara & Kidney & Enterococcus faecalis & MS & Spring 2012 & 849 \\
\hline KJ560974 & $28 \mathrm{~ms}$ & Cachara & Kidney & Enterococcus faecalis & MS & Spring 2012 & 873 \\
\hline KJ560975 & $42 \mathrm{~ms}$ & Cachara & Kidney & Enterococcus faecalis & MS & Spring 2012 & 838 \\
\hline KJ560976 & $43 \mathrm{~ms}$ & Cachara & Kidney & Enterococcus faecalis & MS & Spring 2012 & 864 \\
\hline KJ560977 & $37 \mathrm{~ms}$ & Cachara & Kidney & Enterococcus faecalis & MS & Spring 2012 & 874 \\
\hline KJ560978 & S14 & Tilapia & Skin & Enterococcus faecalis & Arealva SP & Winter 2011 & 864 \\
\hline KJ560979 & $26 \mathrm{~ms}$ & Cachara & Kidney & Enterococcus sulfureus & MS & Spring 2012 & 850 \\
\hline KJ560980 & 20b dp & Tilapia & Gills & Klebsiella pneumoniae & Porto Ferreira SP & Fall 2014 & 819 \\
\hline KJ560981 & $46 \mathrm{MS}$ & Cachara & Skin & Klebsiella pneumoniae & MS & Spring 2012 & 855 \\
\hline KJ560982 & B1 & Tilapia & Skin & Kurthia gibsonii & Arealva SP & Spring 2011 & 837 \\
\hline KJ560983 & A71 & Tilapia & Skin & Lactococcus garviae & Arealva SP & Winter 2011 & 834 \\
\hline KJ560984 & A74 & Tilapia & Kidney & Lactococcus garviae & Arealva SP & Winter 2011 & 855 \\
\hline KJ560985 & $497 \mathrm{FG}$ & Tilapia & Brain & Lactococcus garviae & Rio Paranapanema (SP/PR) & Spring 2012 & 789 \\
\hline KJ560986 & $491 \mathrm{FG}$ & Tilapia & Brain & Lactococcus garviae & Rio Paranapanema (SP/PR) & Spring 2012 & 843 \\
\hline KJ560987 & Zo1 & Tilapia & Kidney & Lactococcus garviae & Guaíra SP & Fall 2014 & 865 \\
\hline KJ560988 & Zo2 & Tilapia & Kidney & Lactococcus garviae & Guaíra SP & Fall 2014 & 866 \\
\hline KJ560989 & $6 n$ & Tilapia & Skin & Lactococcus garviae & Nepean, Jaboticabal SP & Spring 2013 & 875 \\
\hline KJ560990 & A62 & Tilapia & Skin & Lactococcus garviae & Arealva SP & Winter 2011 & 845 \\
\hline KJ560991 & $15 \mathrm{~ms}$ & Cachara & Kidney & Lactococcus garviae & MS & Spring 2012 & 846 \\
\hline KJ560992 & $14 \mathrm{~ms}$ & Cachara & Kidney & Lactococcus garviae & MS & Spring 2012 & 853 \\
\hline KJ560993 & $31 \mathrm{~ms}$ & Cachara & Kidney & Lactococcus garviae & MS & Spring 2012 & 866 \\
\hline KJ560994 & $33 \mathrm{~ms}$ & Cachara & Kidney & Lactococcus garviae & MS & Spring 2012 & 853 \\
\hline KJ560995 & $36 \mathrm{~ms}$ & Cachara & Kidney & Lactococcus garviae & MS & Spring 2012 & 810 \\
\hline KJ560996 & 52MS & Cachara & Brain & Lactococcus garviae & MS & Spring 2012 & 810 \\
\hline KJ560997 & S11 & Tilapia & Skin & Lactococcus garviae & Arealva SP & Winter 2011 & 799 \\
\hline KJ560998 & 9MS & Cachara & Brain & Lactococcus lactis subsp. cremoris & MS & Spring 2012 & 807 \\
\hline
\end{tabular}




\section{Continued}

\begin{tabular}{|c|c|c|c|c|c|c|c|}
\hline KJ560999 & $499 \mathrm{FG}$ & Tilapia & Brain & Lactococcus lactis subsp. cremoris & Rio Paranapanema (SP/PR) & Spring 2012 & 799 \\
\hline KJ561000 & S17 & Tilapia & Skin & Lactococcus lactis subsp. lactis & Caunesp, Jaboticabal SP & Winter 2011 & 869 \\
\hline KJ561001 & $17 \mathrm{~ms}$ & Cachara & Kidney & Lactococcus lactis subsp. lactis & MS & Spring 2012 & 852 \\
\hline KJ561002 & $18 \mathrm{~ms}$ & Cachara & Kidney & Lactococcus lactis subsp. Lactis & MS & Spring 2012 & 861 \\
\hline KJ561003 & $20 \mathrm{~ms}$ & Cachara & Kidney & Citrobacter freundii & MS & Spring 2012 & 842 \\
\hline KJ561004 & $24 \mathrm{~ms}$ & Cachara & Kidney & Lactococcus lactis subsp. Lactis & MS & Spring 2012 & 858 \\
\hline KJ561005 & $500 \mathrm{FG}$ & Tilapia & Brain & Lactococcus lactis subsp. lactis & Rio Paranapanema (SP/PR) & Spring 2012 & 829 \\
\hline KJ561006 & $39 \mathrm{~ms}$ & Cachara & Kidney & Lactococcus lactis subsp. Lactis & MS & Spring 2012 & 832 \\
\hline KJ561007 & $41 \mathrm{~ms}$ & Cachara & Kidney & Lactococcus lactis subsp. lactis & MS & Spring 2012 & 836 \\
\hline KJ561008 & $111 \mathrm{FG}$ & Tilapia & Brain & Lactococcus lactis subsp. lactis & Rio Paranapanema (SP/PR) & Spring 2012 & 845 \\
\hline KJ561009 & $498 \mathrm{FG}$ & Tilapia & Brain & Lactococcus lactis subsp. lactis & Rio Paranapanema (SP/PR) & Spring 2012 & 858 \\
\hline KJ561010 & S8 & Tambaqui & Skin & Lactococcus lactis subsp. lactis & Arealva SP & Winter 2011 & 862 \\
\hline KJ561011 & A15 & Tilapia & Brain & Lactococcus raffinolactis & Caunesp, Jaboticabal SP & Winter 2011 & 859 \\
\hline KJ561012 & $505 \mathrm{FG}$ & Tilapia & Brain & Lactococcus raffinolactis & Rio Paranapanema (SP/PR) & Spring 2012 & 839 \\
\hline KJ561013 & A3 & Tambaqui & Skin & Leucobacter aridicollis & Caunesp, Jaboticabal SP & Winter 2011 & 830 \\
\hline KJ561014 & 1sil & Pacu & Kidney & Aeromonas hydrophila & Caunesp, Jaboticabal SP & Fall 2014 & 865 \\
\hline KJ561015 & 5 sil & Pacu & Kidney & Aeromonas hydrophila & Caunesp, Jaboticabal SP & Fall 2014 & 877 \\
\hline KJ561016 & 10dp & Tilapia & Skin & Aeromonas hydrophila & Porto Ferreira SP & Spring 2013 & 866 \\
\hline KJ561017 & 9dp & Tilapia & Gills & Aeromonas hydrophila & Porto Ferreira SP & Spring 2013 & 867 \\
\hline KJ561018 & A129 & Tilapia & Kidney & Aeromonas hydrophila & Arealva SP & Winter 2011 & 858 \\
\hline KJ561019 & Atcc7966 & Tilapia & Enviroment & Aeromonas hydrophila & RJ & Summer 2011 & 1867 \\
\hline KJ561020 & A130 & Tilapia & Skin & Aeromonas hydrophila & Arealva SP & Winter 2011 & 846 \\
\hline KJ561021 & A122 & Pintado & Skin & Aeromonas hydrophila & Arealva SP & Winter 2011 & 846 \\
\hline KJ561022 & A133 & Tilapia & Skin & Aeromonas hydrophila & Arealva SP & Winter 2011 & 851 \\
\hline KJ561023 & $41 \mathrm{FG}$ & Tilapia & Kidney & Aeromonas hydrophila & Rio Paranapanema (SP/PR) & Spring 2012 & 861 \\
\hline KJ561024 & A128 & Tilapia & Skin & Aeromonas hydrophila & Arealva SP & Winter 2011 & 855 \\
\hline KJ561025 & A135 & Carpa & Skin & Aeromonas hydrophila & RJ & Summer 2011 & 1862 \\
\hline KJ561026 & $117 \mathrm{FG}$ & Tilapia & Kidney & Aeromonas hydrophila & Rio Paranapanema (SP/PR) & Spring 2012 & 854 \\
\hline KJ561027 & $120 \mathrm{FG}$ & Tilapia & Kidney & Aeromonas hydrophila & Rio Paranapanema (SP/PR) & Spring 2012 & 821 \\
\hline KJ561028 & $121 \mathrm{FG}$ & Tilapia & Kidney & Aeromonas hydrophila & Rio Paranapanema (SP/PR) & Spring 2012 & 817 \\
\hline KJ561029 & $125 \mathrm{FG}$ & Tilapia & Kidney & Aeromonas hydrophila & Rio Paranapanema (SP/PR) & Spring 2012 & 839 \\
\hline KJ561030 & $126 \mathrm{FG}$ & Tilapia & Kidney & Aeromonas hydrophila & Rio Paranapanema (SP/PR) & Spring 2012 & 694 \\
\hline KJ561031 & $128 \mathrm{FG}$ & Tilapia & Kidney & Aeromonas hydrophila & Rio Paranapanema (SP/PR) & Spring 2012 & 656 \\
\hline KJ561032 & 14dp & Tilapia & Kidney & Aeromonas jandaei & Porto Ferreira SP & Spring 2013 & 864 \\
\hline KJ561033 & A124 & Tilapia & Brain & Aeromonas jandaei & Arealva SP & Winter 2011 & 865 \\
\hline KJ561034 & A110 & Pintado & Skin & Aeromonas punctata & Arealva SP & Winter 2011 & 843 \\
\hline
\end{tabular}




\begin{tabular}{|c|c|c|c|c|c|c|c|}
\hline \multicolumn{8}{|l|}{ Continued } \\
\hline KJ561035 & 7 sil & Pacu & Kidney & Aeromonas veronii & Caunesp, Jaboticabal SP & Fall 2014 & 750 \\
\hline KJ561036 & an & Tilapia & Kidney & Aeromonas veronii & Nepean, Jaboticabal SP & Fall 2014 & 806 \\
\hline KJ561037 & 6 sil & Pacu & Kidney & Aeromonas veronii & Caunesp, Jaboticabal SP & Fall 2014 & 870 \\
\hline KJ561038 & $5 n$ & Tilapia & Skin & Aeromonas veronii & Nepean, Jaboticabal SP & Spring 2013 & 880 \\
\hline KJ561039 & 1dp & Tilapia & Kidney & Aeromonas veronii & Porto Ferreira SP & Spring 2013 & 779 \\
\hline KJ561040 & A107 & Pintado & Brain & Aeromonas veronii & Arealva SP & Winter 2011 & 859 \\
\hline KJ561041 & A115 & Pintado & Brain & Aeromonas veronii & Arealva SP & Winter 2011 & 835 \\
\hline KJ561042 & A131 & Tilapia & Brain & Aeromonas veronii & Arealva SP & Winter 2011 & 854 \\
\hline KJ561043 & A119 & Pintado & Brain & Aeromonas veronii & Arealva SP & Winter 2011 & 821 \\
\hline KJ561044 & A116 & Pintado & Brain & Aeromonas veronii & Arealva SP & Winter 2011 & 839 \\
\hline KJ561045 & A113 & Pintado & Kidney & Aeromonas veronii & Arealva SP & Winter 2011 & 833 \\
\hline KJ561046 & A109 & Pintado & Brain & Aeromonas veronii & Arealva SP & Winter 2011 & 869 \\
\hline KJ561047 & A134 & Carpa & Skin & Aeromonas veronii & $\mathrm{RJ}$ & Summer 2011 & 855 \\
\hline KJ561048 & A136 & Carpa & Skin & Aeromonas veronii & $\mathrm{RJ}$ & Summer 2011 & 853 \\
\hline KJ561049 & A112 & Pintado & Muco & Aeromonas veronii & Arealva SP & Winter 2011 & 860 \\
\hline KJ561050 & 124 FG & Tilapia & Brain & Streptococcus agalactiae & Rio Paranapanema (SP/PR) & Spring 2012 & 806 \\
\hline KJ561051 & Zo5 & Tilapia & Brain & Streptococcus agalactiae & Guaíra SP & Fall 2014 & 850 \\
\hline KJ561052 & Zo9s & Tilapia & Brain & Streptococcus agalactiae & Guaíra SP & Fall 2014 & 866 \\
\hline KJ561053 & $78 \mathrm{FG}$ & Tilapia & Brain & Streptococcus agalactiae & Rio Paranapanema (SP/PR) & Spring 2012 & 854 \\
\hline KJ561054 & 99 FG & Tilapia & Brain & Streptococcus agalactiae & Rio Paranapanema (SP/PR) & Spring 2012 & 865 \\
\hline KJ561055 & $103 \mathrm{FG}$ & Tilapia & Brain & Streptococcus agalactiae & Rio Paranapanema (SP/PR) & Spring 2012 & 865 \\
\hline KJ561056 & $100 \mathrm{FG}$ & Tilapia & Brain & Streptococcus agalactiae & Rio Paranapanema (SP/PR) & Spring 2012 & 863 \\
\hline KJ561057 & 104 FG & Tilapia & Brain & Streptococcus agalactiae & Rio Paranapanema (SP/PR) & Spring 2012 & 859 \\
\hline KJ561058 & 76 FG & Tilapia & Brain & Streptococcus agalactiae & Rio Paranapanema (SP/PR) & Spring 2012 & 871 \\
\hline KJ561059 & 105 FG & Tilapia & Brain & Streptococcus agalactiae & Rio Paranapanema (SP/PR) & Spring 2012 & 864 \\
\hline KJ561060 & 77 FG & Tilapia & Brain & Streptococcus agalactiae & Rio Paranapanema (SP/PR) & Spring 2012 & 866 \\
\hline KJ561061 & 106 FG & Tilapia & Brain & Streptococcus agalactiae & Rio Paranapanema (SP/PR) & Spring 2012 & 865 \\
\hline KJ561062 & 102 FG & Tilapia & Brain & Streptococcus agalactiae & Rio Paranapanema (SP/PR) & Spring 2012 & 853 \\
\hline KJ561063 & $18 \mathrm{P}$ & Tilapia & Fígado & Streptococcus agalactiae & Itambaracá PR & Fall 2010 & 840 \\
\hline KJ561064 & $74 \mathrm{P}$ & Tilapia & Brain & Streptococcus agalactiae & Itambaracá PR & Fall 2011 & 789 \\
\hline KJ561065 & $26 \mathrm{P}$ & Tilapia & Kidney & Streptococcus agalactiae & Itambaracá PR & Fall 2011 & 855 \\
\hline KJ561066 & $45 \mathrm{P}$ & Tilapia & Kidney & Streptococcus agalactiae & Itambaracá PR & Winter 2011 & 831 \\
\hline KJ561067 & $36 \mathrm{P}$ & Tilapia & Fígado & Streptococcus agalactiae & Itambaracá PR & Summer 2011 & 853 \\
\hline KJ561068 & $43 \mathrm{P}$ & Tilapia & Brain & Streptococcus agalactiae & Itambaracá PR & Winter 2011 & 603 \\
\hline KJ561069 & $110 \mathrm{FG}$ & Tilapia & Brain & Streptococcus agalactiae & Rio Paranapanema (SP/PR) & Spring 2012 & 422 \\
\hline KJ561070 & M & Tilapia & Brain & Streptococcus agalactiae & Itambaracá PR & Fall 2011 & 853 \\
\hline
\end{tabular}




\section{Continued}

\begin{tabular}{|c|c|c|c|c|c|c|c|}
\hline KJ561071 & $64 \mathrm{P}$ & Tilapia & Brain & Streptococcus agalactiae & Itambaracá PR & Winter 2011 & 681 \\
\hline KJ561072 & 112 FG & Tilapia & Brain & Streptococcus agalactiae & Rio Paranapanema (SP/PR) & Spring 2012 & 846 \\
\hline KJ561073 & Zo4 & Tilapia & Brain & Streptococcus iniae & Guaíra SP & Fall 2014 & 839 \\
\hline KJ561074 & Zo7 & Tilapia & Brain & Streptococcus iniae & Guaíra SP & Fall 2014 & 839 \\
\hline KJ561075 & $79 \mathrm{FG}$ & Tilapia & Brain & Streptococcus iniae & Rio Paranapanema (SP/PR) & Summer 2012 & 859 \\
\hline KJ561076 & $81 \mathrm{FG}$ & Tilapia & Brain & Streptococcus iniae & $\begin{array}{l}\text { Reservatório de Ilha Sol- } \\
\text { teira, rio Paraná SP }\end{array}$ & Summer 2012 & 862 \\
\hline KJ561077 & $40 \mathrm{~ms}$ & Cachara & Kidney & Streptococcus dysgalactiae & MS & Spring 2012 & 846 \\
\hline KJ561078 & $52 \mathrm{P}$ & Tilapia & Kidney & Weissella confusa & Itambaracá PR & Summer 2011 & 852 \\
\hline KJ561079 & $23 F G$ & Tilapia & Skin & Acinetobacter johnsonii & Rio Paranapanema (SP/PR) & Spring 2012 & 843 \\
\hline KJ561080 & $\mathrm{C} 1$ & Carpa & Skin & Acinetobacter tjernbergiae & RJ & Summer 2011 & 819 \\
\hline KJ561081 & 30 AM FG & Tilapia & Skin & Acinetobacter radioresistens & Rio Paranapanema (SP/PR) & Spring 2012 & 850 \\
\hline KJ561082 & 84AM FG & Tilapia & Skin & Acinetobacter ursingii & Rio Paranapanema (SP/PR) & Spring 2012 & 849 \\
\hline KJ561083 & 96AM FG & Tilapia & Skin & Agrobacterium tumefaciens & Rio Paranapanema (SP/PR) & Spring 2012 & 799 \\
\hline KJ561084 & 69ROSA FG & Tilapia & Skin & Arthrobacter globiformis & Rio Paranapanema (SP/PR) & Spring 2012 & 830 \\
\hline KJ561085 & 57MS & Cachara & Skin & Bacillus stratoSPhericus & MS & Spring 2012 & 828 \\
\hline KJ561086 & $22 \mathrm{~ms}$ & Cachara & Kidney & Brevibacillus agri & MS & Spring 2012 & 833 \\
\hline KJ561087 & $23 \mathrm{~ms}$ & Cachara & Kidney & Brevibacillus agri & MS & Spring 2012 & 727 \\
\hline KJ561088 & $16 \mathrm{~ms}$ & Cachara & Skin & Carnobacterium divergens & MS & Spring 2012 & 872 \\
\hline KJ561089 & 11dp & Tilapia & Skin & Citrobacter freundii & Porto Ferreira SP & Spring 2013 & 867 \\
\hline KJ561090 & A108 & Pintado & Brain & Citrobacter freundii & Arealva SP & Winter 2011 & 856 \\
\hline KJ561091 & $44 \mathrm{MS}$ & Cachara & Kidney & Citrobacter freundii & MS & Spring 2012 & 850 \\
\hline KJ561092 & 54MS & Cachara & Kidney & Citrobacter freundii & MS & Spring 2012 & 800 \\
\hline KJ561093 & $1 \mathrm{~g}$ & Pacu & Kidney & Citrobacter freundii & Caunesp, Jaboticabal SP & Spring 2013 & 779 \\
\hline KJ561094 & A99 & Catfish & Baço & Citrobacter murliniae & Dourados ms & Winter 2011 & 860 \\
\hline KJ561095 & 115 FG & Tilapia & Skin & Pseudomonas chlororaphis & Rio Paranapanema (SP/PR) & Spring 2012 & 752 \\
\hline KJ561096 & A78 & Tilapia & Skin & Pseudomonas fulva & Arealva SP & Winter 2011 & 845 \\
\hline KJ561097 & A75 & Tilapia & Kidney & Pseudomonas fulva & Arealva SP & Winter 2011 & 813 \\
\hline KJ561098 & 116 FG & Tilapia & Skin & Pseudomonas fulva & Rio Paranapanema (SP/PR) & Spring 2012 & 826 \\
\hline KJ561099 & 114 FG & Tilapia & Skin & Pseudomonas libanensis & Rio Paranapanema (SP/PR) & Spring 2012 & 827 \\
\hline KJ561100 & 93FG & Tilapia & Kidney & Pseudomonas monteilii & Rio Paranapanema (SP/PR) & Spring 2012 & 846 \\
\hline KJ561101 & A76 & Tilapia & Skin & Pseudomonas mosselii & Arealva SP & Winter 2011 & 844 \\
\hline KJ561102 & A82 & Tilapia & Skin & Pseudomonas mosselii & Arealva SP & Winter 2011 & 818 \\
\hline KJ561103 & A66 & Tambaqui & Skin & Pseudomonas nitroreducens & Arealva SP & Winter 2011 & 821 \\
\hline KJ561104 & 94FG & Tilapia & Kidney & Pseudomonas plecoglissida & Rio Paranapanema (SP/PR) & Spring 2012 & 854 \\
\hline KJ561105 & 4 sil & Pacu & Gills & Pseudomonas putida & Caunesp, Jaboticabal SP & Fall 2014 & 856 \\
\hline KJ561106 & 2sil & Pacu & Gills & Pseudomonas putida & Caunesp, Jaboticabal SP & Fall 2014 & 850 \\
\hline
\end{tabular}


F. A. Sebastião et al.

\begin{tabular}{|c|c|c|c|c|c|c|c|}
\hline \multicolumn{8}{|l|}{ Continued } \\
\hline KJ561107 & T5-1 & Tilapia & Baço & Pseudomonas putida & Porto Ferreira SP & Spring 2013 & 862 \\
\hline KJ561108 & 3sil & Pacu & Skin & Pseudomonas putida & Caunesp, Jaboticabal SP & Fall 2014 & 690 \\
\hline KJ561109 & 49MS & Cachara & Skin & Pseudomonas stutzeri & MS & Spring 2012 & 850 \\
\hline KJ561110 & 49AM FG & Tilapia & Skin & Stenotrophomonas chelatiphaga & Rio Paranapanema (SP/PR) & Spring 2012 & 858 \\
\hline KJ561111 & 22FG & Tilapia & Skin & Stenotrophomonas maltophilia & Rio Paranapanema (SP/PR) & Spring 2012 & 867 \\
\hline KJ561112 & T3.5b & Tilapia & Skin & Plesiomonas shigelloides & Porto Ferreira SP & Spring 2013 & 864 \\
\hline KJ561113 & A132 & Tilapia & Skin & Comamonas testosteroni & Arealva SP & Winter 2011 & 849 \\
\hline
\end{tabular}

